Published in final edited form as:

Anal Chem. 2018 February 06; 90(3): 2216-2223. doi:10.1021/acs.analchem.7b04590.

\title{
Liquid Chromatography-High Resolution Mass Spectrometry Analysis of Platelet Frataxin as a Protein Biomarker for the Rare Disease Friedreich's Ataxia
}

\author{
Lili Guo ${ }^{\dagger, \ddagger, \|}$, Qingqing Wang ${ }^{\dagger, \ddagger, \|}$, Liwei Weng ${ }^{\dagger}$, Lauren A. Hauser ${ }^{\ddagger, \S,}, \bigcirc$, Cassandra J. \\ Strawser $\$, \S, \bigcirc$, Agostinho G. Rocha $^{\perp, \uparrow}$, Andrew Dancis ${ }^{\perp}$, Clementina Mesaros ${ }^{\dagger, \ddagger}$, David R. \\ Lynch $^{\ddagger}, \S, \bigcirc$, and lan A. Blair ${ }^{\dagger, \ddagger},{ }^{*}, \mathrm{iD}$ \\ tPenn SRP Center and Center of Excellence in Environmental Toxicology Center, Department of \\ Systems Pharmacology and Translational Therapeutics, Perelman School of Medicine, University \\ of Pennsylvania, Philadelphia, Pennsylvania 19104, United States \\ łPenn/CHOP Center of Excellence in Friedreich's Ataxia, Philadelphia, Pennsylvania 19104, \\ United States \\ $\S$ Departments of Pediatrics and Neurology, Children's Hospital of Philadelphia, Philadelphia, \\ Pennsylvania 19104, United States \\ Departments of Pediatrics and Neurology, Perelman School of Medicine, University of \\ Pennsylvania, Philadelphia, Pennsylvania 19104, United States \\ ${ }^{\perp}$ Department of Medicine, Division of Hematology-Oncology, Perelman School of Medicine, \\ University of Pennsylvania, Philadelphia, Pennsylvania 19104, United States
}

\section{Abstract}

Friedreich's ataxia (FA) is an autosomal recessive disease caused by an intronic GAA triplet expansion in the $F X N$ gene, leading to reduced expression of the mitochondrial protein frataxin. FA is estimated to affect 1 in 50000 with a mean age of death in the fourth decade of life. There are no approved treatments for FA, although experimental approaches, which involve upregulation or replacement of frataxin protein, are being tested. Frataxin is undetectable in serum or plasma, and whole blood cannot be used because it is present in long-lived erythrocytes.

\footnotetext{
"Corresponding Author, Tel: +1-215-573-9885. Fax: +1-215-573-9889. ianblair@upenn.edu.

TPresent Address

A.G.R.: Center for Pharmacogenomics, Department of Internal Medicine, Washington University School of Medicine, St. Louis, MO, United States.

"L.G. and Q.W. contributed equally to the work and should be regarded as cofirst authors. ORCID ${ }^{\circ}$

Ian A. Blair: 0000-0003-0366-8658

Supporting Information

The Supporting Information is available free of charge on the ACS Publications website at DOI: 10.1021/acs.analchem.7b04590.

Characteristics of FA patients; PRM transitions for the analysis of tryptic peptides; accuracy and precision for determination of frataxin by stable isotope dilution IP 2D-nano-UHPLC-PRM/MS; purification of frataxin light and SILAC labeled standards; 2D-nano-UHPLC-MS analysis of frataxin standard; amino acid sequence of mature unlabeled frataxin; mass spectra of light and SILAC-labeled frataxin peptides; SDS-PAGE analysis; calibration curves; platelet frataxin tryptic peptide correlations (PDF)
}

The authors declare no competing financial interest. 
Therefore, an assay was developed for analyzing frataxin in platelets, which have a half-life of 10 days. The assay is based on stable isotope dilution immunopurification two-dimensional nanoultra high performance liquid chromatography/parallel reaction monitoring/mass spectrometry. The lower limit of quantification was $0.078 \mathrm{pg}$ frataxin/ $\mu \mathrm{g}$ protein, and the assay had $100 \%$ sensitivity and specificity for discriminating between controls and FA cases. The mean levels of control and FA platelet frataxin were $9.4 \pm 2.6$ and $2.4 \pm 0.6 \mathrm{pg} / \mu \mathrm{g}$ protein, respectively. The assay should make it possible to rigorously monitor the effects of therapeutic interventions on frataxin expression in this devastating disease.

\section{Graphical abstract}

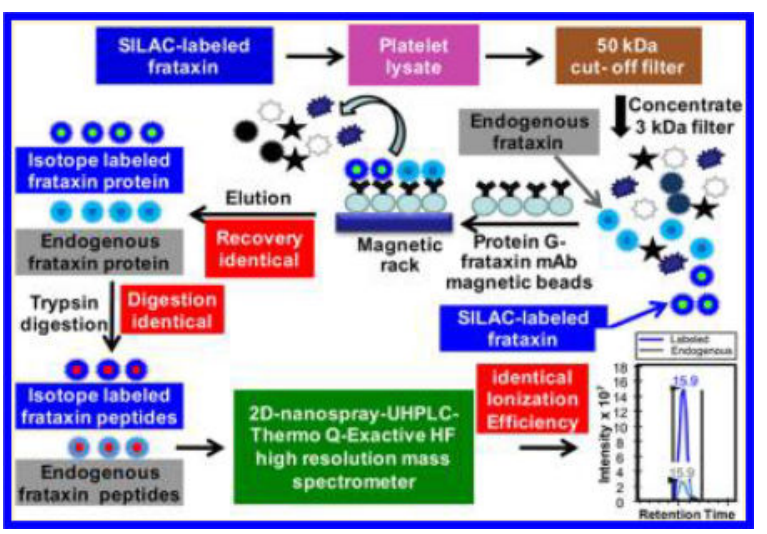

There are $>40$ rare genetic diseases that result from aberrant protein expression, including Duchenne's muscular dystrophy (DMD), ${ }^{1}$ spinocerebellar ataxia 1 (SCA-1), ${ }^{2}$ and

Friedreich's ataxia (FA). ${ }^{3}$ Current approaches to developing therapies for these rare diseases primarily involve increasing expression of the normal protein. The necessity for monitoring protein levels was highlighted recently during the US Food and Drug Administration (FDA) fast-track approval process for the drug eteplirsen (Exondys 51) to treat DMD. ${ }^{4}$ The lack of a rigorously validated method to assess upregulation of dystrophin levels in DMD patients made it difficult to show a therapeutic response. This resulted in mobilization of advocate groups to help obtain FDA approval, an approach that will be discouraged in the future. ${ }^{5}$

FA is an autosomal recessive disease estimated to affect 1 in $50000 .^{6}$ The abnormal gene contains an expanded GAA repeat in intron 1, which causes transcriptional silencing and reduced expression of the mitochondrial protein frataxin. ${ }^{7,8}$ Longer GAA repeats, which induce a greater frataxin deficiency, are associated with earlier onset of the disease and increased severity. ${ }^{9}$ A subset of patients $(<3 \%)$ have heterozygous GAA expansions coupled with a loss of function mutation. ${ }^{3,10}$ The exact role of frataxin is not completely understood; it could serve as an iron donor or regulate cysteine-derived persulfide formation during the assembly of mitochondrial iron-sulfur complexes. ${ }^{11,12}$ Reduced frataxin expression results in decreased activity of a number of mitochondrial enzymes involved in energy metabolism. 13

FA is characterized by slowly progressive ataxia ${ }^{14}$ and hypertrophic cardiomyopathy. ${ }^{15}$ Symptoms generally appear during adolescence, and patients on average become wheel- 
chair-bound 15.5 years after the disease onset. ${ }^{16,17}$ Lifespan is significantly reduced in FA with an average of death of 37 years, most commonly from cardiac-related pathologies. ${ }^{15}$ There are no approved treatments for FA, although numerous experimental approaches are being tested, which primarily involve up-regulation of frataxin protein. ${ }^{17-21}$ We have developed a strategy to monitor improvements in mitochondrial metabolism using FA platelets. ${ }^{22,23}$ However, a more direct measure of frataxin expression is also required. This stimulated our development of a sensitive and specific method for the quantification of mature platelet frataxin from FA patients. This method also provides an approach to monitor new therapies that are being developed for rare genetic diseases of aberrant protein expression such as $\mathrm{DMD}^{24}$ and SCA- $1 .{ }^{2}$

The major $F X N$ transcript encodes a full-length 210-amino acid form of frataxin (1-210; Figure 1) with a molecular weight (MW) of $23135 \mathrm{Da}$. It is rapidly translocated to the mitochondria where it is cleaved by mitochondrial processing peptidase (MPP) to the mature active form of frataxin (MW = $14268 \mathrm{Da}$, Figure 1). ${ }^{25-27}$ Mitochondrial mature frataxin (81-210) is not normally secreted into the circulation, which means that in vivo monitoring must be conducted in blood cells rather than serum or plasma. ${ }^{28}$ Surprisingly, substantial amounts of mature frataxin (81-210) are present in erythrocytes from controls $(70 \mathrm{ng} / \mathrm{mL}$ blood $)^{29}$ and FA cases $(17 \mathrm{ng} / \mathrm{mL} \text { blood })^{29}$ even though they lack mitochondria (Table 1). Erythrocytes have a half-life of approximately 100 days (Table 1), which precludes the use of whole blood because changes would not be detected during clinical trials. In contrast, platelets have $86 \%$ of the mitochondria present in whole blood and a half-life of only 10 days (Table 1) making them an attractive alternative.

A lateral flow immunoassay (dipstick immunoassay, DI) found a significant difference in normal platelet frataxin $(9.4 \mathrm{mAbs} / \mu \mathrm{g}$ protein) compared with FA platelet frataxin (3.2 $\mathrm{mAbs} / \mu \mathrm{g}$ protein), although there was considerable interindividual overlap. ${ }^{28}$ Absolute values reported subsequently for FA peripheral blood mononuclear cells (PBMCs, monocytes, and lymphocytes) of $2.7 \mathrm{pg} / \mu \mathrm{g}$ protein ${ }^{28,29}$ (corresponding to $9.0 \mathrm{mAbs} / \mu \mathrm{g}$ protein $^{28}$ ) made it possible to estimate that low levels of frataxin are present in normal control platelets (2.8 $\mathrm{pg} / \mu \mathrm{g}$ protein) and FA platelets $(1.0 \mathrm{pg} / \mu \mathrm{g}$ protein) (Table 1$)$. The low overlapping levels, ${ }^{28}$ and the minimal amount of available blood, led to our development of an immunopurification two-dimensional-nano-ultra high performance liquid chromatography-parallel reaction monitoring/mass spectrometry (IP 2D-nano-UHPLCPRM/MS) assay for platelet frataxin. We report the rigorous validation and utility of the assay.

\section{EXPERIMENTAL SECTION}

\section{Chemicals and Materials}

Reagents and solvents were LC-MS grade quality unless otherwise noted. $\left[{ }^{13} \mathrm{C}_{6}{ }^{15} \mathrm{~N}_{2}\right]$-lysine and $\left[{ }^{13} \mathrm{C}_{6}{ }^{15} \mathrm{~N}_{1}\right.$ ]-leucine were from Cambridge Isotope Laboratories (Andover, MA, USA). Antifrataxin antibody (clone 1D9) was from LifeSpan Biosciences, Inc. (Seattle, WA). Dimethyl pimelimidate dihydrochloride (DMP), EDTA-free protease inhibitor cocktail, D,Ldithiothreitol (DTT), isopropyl- $\beta$-D-thiogalactoside (IPTG), bovine serum albumin (BSA), human lysozyme, imidazole, triethanolamine, ethanolamine, and M9, minimal salts, $5 \times$ 
powder, minimal microbial growth medium (M9 media) were purchased from MilliporeSigma (Billerica, MA). Ni-NTA Agarose resin was purchased from Qiagen (Germantown, MD). LC grade water and acetonitrile were from Burdick and Jackson (Muskegon, MI, USA). Protein G magnetic beads were obtained from Life Technologies Corporation (Grand Island, NY).

\section{Clinical Samples}

Blood samples were obtained from FA patients (Table S-1; average age 34.3) and unaffected control subjects ( 3 males, 4 females, average age 32.6). They all are enrolled in an ongoing natural history study at the Children's Hospital of Philadelphia (IRB \# 01-002609).

\section{Platelet Isolation}

Venous blood was drawn into $8.5 \mathrm{~mL}$ acid-citrate-dextrose Vacutainer tubes. Blood (4 mL) was transferred to $15 \mathrm{~mL}$ polypropylene tubes and spun at $200 \mathrm{~g}$ for $13 \mathrm{~min}$ at room temperature with no brakes as described previously. ${ }^{23}$ The platelet pellet was carefully washed twice with $0.5 \mathrm{~mL}$ platelet wash buffer $(10 \mathrm{mM}$ sodium citrate, $150 \mathrm{mM} \mathrm{NaCl}, 1$ $\mathrm{mM}$ EDTA, $1 \%(\mathrm{w} / \mathrm{v})$ glucose, $\mathrm{pH}$ 7.4) by spinning at $800 \mathrm{~g}$ for $5 \mathrm{~min}$. All platelet samples were immediately frozen at $-80{ }^{\circ} \mathrm{C}$ after preparation until analysis.

\section{Expression and Purification of Unlabeled and SILAC-Labeled Frataxin}

The coding sequence of human frataxin (81-210) was amplified by PCR reaction from the FXN cDNA plasmid (pTL1), which was a kind gift from Dr. M. Koenig. ${ }^{30}$ The amplified FXN fragment was cloned into a pET21b plasmid and linked to the $6 \times$ histidine (His) sequence through the XhoI site at the $3^{\prime}$ end. The $6 \times$ His-tag fusion of frataxin was expressed in Escherichia coli BL21 DE3 in M9 media containing $1 \mathrm{mM} \mathrm{MgSO}_{4}, 10 \mu \mathrm{M}$ $\mathrm{CaCl}_{2}$, and $0.5 \%$ glucose with $100 \mathrm{mg} / \mathrm{L}$ ampicillin. For expressing unlabeled frataxin, M9 medium was supplemented with $0.025 \%$ leucine and lysine. For expressing stable isotope labeling by amino acids in cell culture (SILAC)-labeled frataxin, M9 medium was supplemented with $0.025 \%\left[{ }^{13} \mathrm{C}_{6}{ }^{15} \mathrm{~N}_{1}\right]$-leucine and $\left[{ }^{13} \mathrm{C}_{6}{ }^{15} \mathrm{~N}_{2}\right]$-lysine. Cells were precultured in $2 \mathrm{~mL}$ of corresponding $\mathrm{M} 9$ medium overnight at $37{ }^{\circ} \mathrm{C}$ (Figure $\mathrm{S}-1$, lanes 1 and 4). The next day, the bacteria were grown in $250 \mathrm{~mL}$ of medium at $37^{\circ} \mathrm{C}$ to an absorbance at $600 \mathrm{~nm}$ of $0.9-1.0$ and were induced for protein expression with $1 \mathrm{mM}$ IPTG for $4 \mathrm{~h}$ at $30^{\circ} \mathrm{C}$. Cells were pelleted and resuspended in $10 \mathrm{~mL}$ of lysis buffer $(50 \mathrm{mM}$ Tris$\mathrm{HCl}$ (pH 8.0), $500 \mathrm{mM} \mathrm{NaCl}, 10 \mathrm{mM}$ imidazole, $10 \%$ glycerol, $2 \mathrm{mM} \beta$-mercaptoethanol, $2 \times$ protease inhibitor cocktail, $1 \mathrm{mM}$ PMSF). Cell pellets were then lysed by addition of 100 $\mu \mathrm{L}$ of $10 \mathrm{mg} / \mathrm{mL}$ human lysozyme and incubated on ice for $30 \mathrm{~min}$ followed by $6 \times 20 \mathrm{~s}$ probe sonication (Figure S-1, lanes 2 and 5). The samples were spun at $20000 \mathrm{~g}$ for $30 \mathrm{~min}$, and the supernatants were incubated with $200 \mu \mathrm{L}$ of Ni-NTA resin for $1 \mathrm{~h}$ at $4{ }^{\circ} \mathrm{C}$. The resin was washed twice with $10 \mathrm{~mL}$ of washing buffer $(50 \mathrm{mM}$ Tris- $\mathrm{HCl}(\mathrm{pH} 8.0), 500 \mathrm{mM} \mathrm{NaCl}$, $20 \mathrm{mM}$ imidazole, $10 \%$ glycerol, $2 \mathrm{mM} \beta$-mercaptoethanol, $2 \times$ protease inhibitor cocktail). Frataxin was eluted by incubating the resin with $3 \times 150 \mu \mathrm{L}$ of elution buffer $(50 \mathrm{mM}$ Tris$\mathrm{HCl}(\mathrm{pH}$ 8.0), $500 \mathrm{mM} \mathrm{NaCl}, 400 \mathrm{mM}$ imidazole, $10 \%$ glycerol, $2 \mathrm{mM} \beta$-mercaptoethanol, $2 \times$ protease inhibitor cocktail). The purity of the unlabeled His-tagged frataxin is shown in Figure S-1, lane 3. His-tagged SILAC-labeled frataxin (Figure S-1, lane 6) was found to be $>95 \%$ pure by SDS-PAGE and Coomassie blue staining. 
To determine the unlabeled frataxin concentration, imidazole was removed by concentrating $100 \mu \mathrm{L}$ of frataxin eluate in an Amicon $3 \mathrm{kDa}, 0.5 \mathrm{~mL}$ filter to $<15 \mu \mathrm{L}$ and refilling the filter unit with phosphate-buffered saline (PBS) at $4{ }^{\circ} \mathrm{C}$. This step was repeated 5 times, and the purified protein was suspended in $100 \mu \mathrm{L}$ of PBS. The frataxin concentration was determined by measuring the absorption at $280 \mathrm{~nm}$ and using the extinction coefficient $\left(\lambda_{\max }\right)=26930 \mathrm{M}^{-1} \mathrm{~cm}^{-1}$ (predicted by the amino acid sequence). ${ }^{31}$ The concentration of the unlabeled standard was verified by comparing frataxin bands with bands from known amounts of BSA in a Coomassie blue stained SDS-PAGE gel. The concentration of the SILAC-labeled frataxin internal standard was determined by comparing it with endogenous frataxin bands and BSA bands in a Coomassie blue stained SDS-PAGE gel. Frataxin standards were stored in PBS containing $1 \mathrm{mM}$ DTT mixed with $50 \%$ glycerol at $-20{ }^{\circ} \mathrm{C}$. For long-term storage, the standards were kept at $-80^{\circ} \mathrm{C}$.

\section{DMP Cross-Linking of mAb with Magnetic Beads}

Protein G magnetic beads were washed twice with PBS before use. $80 \mu \mathrm{g}$ of antifrataxin $\mathrm{mAb}$ (1D9) was incubated with $10 \mathrm{mg}$ of protein $\mathrm{G}$ beads for $1 \mathrm{~h}$ at room temperature or $4{ }^{\circ} \mathrm{C}$ overnight. The antibody solution was removed, and beads were washed twice with 1 $\mathrm{mL}$ of cross-linking buffer ( $0.2 \mathrm{M}$ triethanolamine, $\mathrm{pH}$ 8.2). Antibody bound protein $\mathrm{G}$ beads were incubated with $2 \mathrm{~mL}$ of freshly prepared DMP solution $(13 \mathrm{mg} / \mathrm{mL}$ in crosslinking buffer) at room temperature for $45 \mathrm{~min}$ on a rotator. DMP solution was removed, and beads were washed twice with $2 \mathrm{~mL}$ of blocking buffer (0.1 M ethanolamine, $\mathrm{pH}$ 8.2).

Blocking buffer was removed, and beads were washed twice with $2 \mathrm{~mL}$ of PBS. The beads were quickly rinsed with $2 \mathrm{~mL}$ of $0.1 \mathrm{M}$ glycine- $\mathrm{HCl}(\mathrm{pH} 3)$ and washed three times with 2 $\mathrm{mL}$ of PBS. The beads were stored in $500 \mu \mathrm{L}$ of PBS at $4{ }^{\circ} \mathrm{C}$. The antibody coupled beads were shown to be effective 3 weeks after preparation with $0.02 \%$ sodium azide included in PBS. For preparation of larger amounts, reagents were scaled up accordingly.

\section{Cell Lysate Preparation}

Frozen platelet pellets were lysed in $180 \mu \mathrm{L}$ of ice cold IP-lysis buffer (50 mM Tris, $\mathrm{pH} 7.5$, $150 \mathrm{mM} \mathrm{NaCl}, 0.5 \%$ Triton X-100, 0.5\% NP-40, $1 \mathrm{mM} \mathrm{DTT)} \mathrm{supplemented} \mathrm{with} 1 \times$ complete protease cocktail and incubated on ice for $15 \mathrm{~min}$. Cell lysates $(4 \mu \mathrm{L})$ were taken for protein concentration measurement by the Bradford assay (Bio-Rad, Hercules, CA). A SILAC-labeled frataxin internal standard (20 ng) was spiked in before addition of $20 \mu \mathrm{L}$ of $10 \%$ SDS solution to reach a $1 \%$ final SDS concentration. Samples were mixed and heated at $95{ }^{\circ} \mathrm{C}$ for $5 \mathrm{~min}$. For viscous samples, pulse sonication was applied for $30 \mathrm{~s}$ using a sonic dismembranator (Fisher). Samples were centrifuged at $16000 \mathrm{~g}$ using a benchtop centrifuge for $15 \mathrm{~min}$ at room temperature. The supernatants were diluted 10 times by adding $1.8 \mathrm{~mL}$ of IP lysis buffer with protease inhibitor before being applied to the Amicon Ultracel-50K filters (MilliporeSigma, Burlington MA). The filters were spun at $4000 g, 4^{\circ} \mathrm{C}$ for $20 \mathrm{~min}$. The flow-through was transferred to Amicon Ultracel-3K filter units and spun at $4000 g, 4{ }^{\circ} \mathrm{C}$ for 20 min until the sample volume was concentrated to less than $300 \mu \mathrm{L}$. Samples were transferred to clean Eppendorf Protein LoBind tubes (Eppendorf, Hamburg, Germany) for immunoprecipitation. 


\section{Western Blot and Gel Staining}

Frataxin was detected by mAb antifrataxin (Abcam, Cambridge, MA) and antimouse HRP

(Santa Cruz Biotechnology, Dallas, TX). Western blots were developed using ECL reagents. Gels were stained with colloidal Coomassie (Promega, Madison, WI).

\section{Intact Protein Analysis by High-Resolution MS}

Samples were infused into a Q Exactive HF Hybrid Quadrupole-Orbitrap mass spectrometer equipped with a HESI probe with a flow rate of $3 \mu \mathrm{L} / \mathrm{min}$. MS operating conditions were as follows: spray voltage, $4000 \mathrm{~V}$; ion transfer capillary temperature, $300{ }^{\circ} \mathrm{C}$; ion polarity, positive; S-lens RF level, 60; in-source CID, $80 \mathrm{eV}$; resolution, 60 000; microscan, 10.

\section{Immunoprecipitation and Trypsin Digestion}

Samples were incubated with $0.3 \mathrm{mg}$ of DMP cross-linked antifrataxin protein beads at $4{ }^{\circ} \mathrm{C}$ overnight in protein LoBind tubes. The unbound samples were removed; the beads were resuspended in $500 \mu \mathrm{L}$ of IP lysis buffer and then transferred to clean LoBind tubes.

Samples were washed 3 times with $1 \mathrm{~mL}$ of PBS, and frataxin was eluted by incubating the beads with $100 \mu \mathrm{L}$ of elution buffer (300 mM acetic acid in $10 \%$ acetonitrile) with shaking for $15 \mathrm{~min}$. The elutes were transferred to deactivated glass inserts (Waters, Milford, MA) and dried under nitrogen flow. Samples were dissolved in $25 \mathrm{mM}$ aqueous $\mathrm{NH}_{4} \mathrm{HCO}_{3}(50$ $\mu \mathrm{L}$ ) containing $100 \mathrm{ng}$ of trypsin and incubated at $37^{\circ} \mathrm{C}$ overnight before LC-MS analysis.

\section{Frataxin Depletion of Human Platelet Lysates}

Surplus 5-day old human platelets were provided by the Hospital of the University of Pennsylvania. Intact platelets $(80 \mathrm{mg}$ ) were lysed in $8 \mathrm{~mL}$ of IP lysis buffer containing $1 \mathrm{mM}$ DTT and protease inhibitor. Samples were pulse-sonicated for $1 \mathrm{~min}$, and the cell debris was removed by spinning at $16000 \mathrm{~g}$ for $15 \mathrm{~min}$. In the first round of depletion, the supernatant was incubated with $40 \mu \mathrm{g}$ of antifrataxin mAb 1D9 bound to $6 \mathrm{mg}$ of protein G Dynabeads overnight followed by the removal of the beads, which removed approximately $90 \%$ of endogenous frataxin. To maximize the depletion efficiency, lysates were incubated a second time with $80 \mu \mathrm{g}$ of antifrataxin mAb 1D9 bound to $12 \mathrm{mg}$ of protein G Dynabeads for $20 \mathrm{~h}$. The depletion efficiency was first examined by SDS-PAGE and Western blot by loading 70 $\mu \mathrm{g}$ of platelet lysates before and after depletion into a gel. LC-MS was then employed to calculate the efficiency.

\section{Method Validation}

Frataxin-depleted platelet protein and BSA were used for preparation of calibration standards and quality controls (QCs). Calibration standards were prepared by spiking appropriate amounts of the frataxin standard to $500 \mu \mathrm{g}$ of frataxin-depleted platelet lysates or $500 \mu \mathrm{g}$ of BSA to make the final concentrations of $0.078,0.156,0.313,0.625,1.25,2.5,5$, 10,20 , and $40 \mathrm{pg} / \mu \mathrm{g}$ protein. The preparation procedures for QC samples at concentrations of $0.25,2.0$, and $30 \mathrm{pg} / \mu \mathrm{g}$ protein were the same as for the calibration standards. Assay validation was conducted according to US FDA guidance. ${ }^{32}$ Linearity of standard curves was evaluated from 0.078 to $40 \mathrm{pg} / \mu \mathrm{g}$ protein. The lower limit of quantification (LLOQ) of $0.078 \mathrm{pg} / \mu \mathrm{g}$ protein was defined as the lowest QC sample, which could be fitted to the 
calibration curve with a residual of less than $10 \%$ when using BSA as matrix and peak area ratio of analyte to internal standard deviating by $<15 \%$. The accuracy and precision were determined on five replicates of LLOQ, low quality control (LQC), middle quality control (MQC), and high quality control (HQC). QC samples $(n=5)$ were analyzed on the same day (intraday) for the frataxin-depleted platelet protein and BSA matrix. Interday assays were performed for each of the frataxin-depleted platelet protein QC samples on five different days $(n=5)$ and on three different days $(n=3)$ for the BSA matrix QC samples.

\section{D-nano-UHPLC-PRM/HRMS}

MS was conducted using a Q Exactive HF coupled to a Dionex Ultimate 3000 RSLCnano with capillary flow meter chromatographic systems (Thermo Fisher Scientific, San Jose, CA, USA). The 2D system was setup as a preconcentration mode which was composed of a ten-port valve, one nanopump for delivering solvents to the analytical column, and a micropump for delivering solvents to trapping column. The $2 \mathrm{D}$ nanoLC system was controlled by Xcalibur software from the Q-Exactive mass spectrometer. The LC trapping column was an Acclaim PepMap $\mathrm{C}_{18}$ cartridge $(0.3 \mathrm{~mm} \times 5 \mathrm{~mm}, 100 \AA$, Thermo Scientific), and the analytical column was a $\mathrm{C}_{18} \mathrm{AQ}$ nano-LC column with a $10 \mu \mathrm{m}$ pulled tip (75 $\mu \mathrm{m} \times$ $25 \mathrm{~cm}, 3 \mu \mathrm{m}$ particle size; Columntip, New Haven, CT).

Samples $(6 \mu \mathrm{L})$ were injected using the microliter-pickup injection mode. Loading solvent was water/acetonitrile $(99.7: 0.3 ; \mathrm{v} / \mathrm{v})$ containing $0.2 \%$ formic acid. In the sample loading step, the valve stayed in loading position (1-2) with loading solvent at $10 \mu \mathrm{L} / \mathrm{min}$ for $3 \mathrm{~min}$. In the elution and analysis step, the valve stayed in injection position (1-10) at which the trapping column was connected to the nanopump and the analytical column, and samples were back-flushed into the analytical column. Washing of the trapping column using the nanopump was continued until $5 \mathrm{~min}$ before the end of the run. Samples were eluted in the mass spectrometer with a linear gradient at a flow rate of $0.4 \mu \mathrm{L} / \mathrm{min}$. Solvent A was water/ acetonitrile (99.5:0.5; v/v) containing $0.1 \%$ formic acid, and solvent B was acetonitrile/water (98:2, v/v) containing $0.1 \%$ formic acid. The gradient on the analytical column was as follows: $2 \% \mathrm{~B}$ at the start, $5 \% \mathrm{~B}$ at $9 \mathrm{~min}, 27 \% \mathrm{~B}$ at $27 \mathrm{~min}, 95 \% \mathrm{~B}$ at $31 \mathrm{~min}$, held for 14 min, and then re-equilibrated at $2 \%$ B from 48 to $60 \mathrm{~min}$. Nanospray was conducted using Nanospray Flex ion source (Thermo Scientific). MS operating conditions were as follows: spray voltage, $2800 \mathrm{~V}$; ion transfer capillary temperature, $275^{\circ} \mathrm{C}$; ion polarity, positive; Slens RF level, 55; in-source CID, $1.0 \mathrm{eV}$. Both full scan and PRM were used. The full scan parameters were resolution, 120 000; AGC target, $3 \times 10^{6}$; maximum IT, $100 \mathrm{~ms}$; scan range, 400-1300 m/ $z$. The PRM parameters were resolution, 60 000; AGC target, $2 \times 10^{5}$; maximum IT, $80 \mathrm{~ms}$; loop count, 5; isolation window, $2.0 \mathrm{Da}$; NCE, 25. The PRM were scheduled for 27.4 to $29.1 \mathrm{~min}$ for $\mathrm{L}^{136} \mathrm{GGDLGTYVINK}{ }^{147}, 25.5$ to $27.7 \mathrm{~min}$ for $\mathrm{Q}^{153}$ IWLSSPSSGPK $^{164}$, and 28.6 to $31.2 \mathrm{~min}$ for $\mathrm{L}^{198}$ DLSSLAYSGK $^{208}$.

\section{Data Analysis}

Data analysis was performed using Skyline (MacCoss Laboratory, University of Washington, Seattle, WA). ${ }^{33}$ The peak area ratio of each PRM transition for each unlabeled/ light (L) peptide to SILAC-labeled/heavy (H) peptide was calculated by the Skyline software and used for absolute quantification. The peptide ratios were calculated by the average $\mathrm{L} / \mathrm{H}$ 
ratios of the three PRM transitions. Frataxin levels were calculated from the average of the three selected peptides. Interestingly, using the average of three PRM transitions during method validation provided higher accuracy and precision compared with the use of single PRM transitions. Although the use of all three PRM transitions for quantification could have increased the chance of interference, this was not observed during sample validation or analysis of platelet samples. Statistical analysis was performed using GraphPad Prism (v 5.01, GraphPad Software Inc., La Jolla, CA).

\section{RESULTS AND DISCUSSION}

\section{Selection of Frataxin Peptides and PRM Transitions}

The expressed and purified frataxin standard was digested insolution by trypsin, and the proteolytic peptides were analyzed in full scan and PRM modes. Uniqueness of the tryptic peptides was verified by searching the BLAST database in Skyline. ${ }^{33}$ Six potentially useful peptides were selected (Figure S-2), and their precursor and all product ions were assessed for signal intensity in the PRM/MS mode. The early eluting $\mathrm{R}^{165}{ }^{\text {YDWTGK }}{ }^{171}$ and the late eluting $\mathrm{N}^{172}$ WVYSHDGVSLHELLAAELTK ${ }^{192}$ tryptic peptides exhibited signal fluctuations during LC-PRM/MS analysis. $\mathrm{S}^{81}$ GTLGHPGSLEDTYER ${ }^{96}$ is the aminoterminal tryptic peptide derived from mature frataxin (Figure 1). A previous report suggested that there could be a frataxin isoform with a five-amino acid addition $\left(\mathrm{M}^{76} \mathrm{NLRK}{ }^{80}\right)$ at the amino terminus, which would also give rise to this tryptic peptide. ${ }^{34}$ Therefore, $\mathrm{S}^{81}$ GTLGHPGSLEDTYER ${ }^{96}$ was used only as a qualifying peptide, and the three peptides used for quantification were: $\mathrm{L}^{136}$ GGDLGTYVINK ${ }^{147}, \mathrm{Q}^{153}$ IWLSSPSSGPK $^{164}$, and L $^{198}$ DLSSLAYSGK $^{208}$ (Figure 2A).

Precursor ions of the peptides generated from pure protein standards presented 2-10-fold higher signals detected in full scan mode compared to signals of the most intense product ions detected in PRM mode. However, the precursor ions had interfering signals or were even not detected when the endogenous frataxin level was $<0.6 \mathrm{pg} / \mu \mathrm{g}$ protein in platelet protein. In contrast, some product ions provided excellent signals for frataxin levels even below $0.05 \mathrm{pg} / \mu \mathrm{g}$ protein. Therefore, the three most intense product ions were used for PRM of both the endogenous frataxin (Figure 2A, Table S-2) and SILAC-labeled internal standard (Figure 2B, Table S-2).

\section{Preparation of Frataxin Protein Standard and SILAC-Labeled Internal Standard}

Both the endogenous and SILAC-labeled proteins were purified from E. coli with a twoamino acid linker (LE) and His tag (HHHHHH) at the carboxyl terminus (Figure S-3). The linker to the protein and the His-tag increased the mass of the unlabeled standard and SILAC-labeled standard by 1055 and $1269 \mathrm{Da}$, respectively (Figure S-3). This caused a slight reduction in mobility when compared with the endogenous frataxin, which was extremely useful for evaluating the efficiency of processing procedures by Western blot (see below). Because commercial frataxin protein standards are either the intermediate or the precursor forms of frataxin or have long extended linker and tags, the purified E. coli expressed frataxin ( $>95 \%$ purity) was used as an authentic standard for assay validation. The protein concentration was determined by UV with extinction coefficient $=26930 \mathrm{M}^{-1} \mathrm{~cm}$ 
${ }^{-1} .31$ The calculated frataxin concentration determined from its UV absorbance was also consistent with the amount estimated by comparing it on SDS-PAGE with the concentrations of BSA standards determined by Coomassie blue staining.

Trypsin digestion of SILAC-labeled frataxin revealed $>99.8 \%$ \{heavy/(light + heavy) labeling efficiency based on the PRM transitions for the three peptides (Figure 2, Table S-2). Interestingly, when the endogenous and SILAC-labeled frataxin proteins were mixed at a 1:1 ratio, the signal intensity for the precursor protonated molecule of the labeled peptide (such as $\mathrm{L}^{198}$ DLSSLAYSGK ${ }^{208}$ ) was generally lower than the corresponding endogenous peptide (Figure S-4). This was because SILAC labeling of frataxin in E. coli resulted in significant M-1, M-2, and M-3 isotopic peaks (Figure S-4). This was not due to the differences of isotopic composition in the amino acid substrates and so most likely occurred through exchange of the $\left[{ }^{15} \mathrm{~N}\right]$-labeled leucine by transamination during the labeling process. In support of this concept, transamination of leucine is known to occur in E. coli. ${ }^{35}$ Furthermore, the increase in M-1, M-2, and M-3 correlated with the number of leucine residues $(1,2$, or 3; Figure $S-4)$. Fortunately, the differences in isotopic composition of the labeled tryptic peptide standards did not cause any interference in the PRM transitions that were used to monitor the endogenous tryptic peptides. This meant that there was no effect on the assay sensitivity or specificity. However, incomplete labeling of the SILAC frataxin standard meant that, when standard curves were constructed for each peptide separately, the slopes were slightly different, but the back calculated frataxin values were highly consistent (see below). Different lots of the frataxin SILAC standard can be prepared with no interference into the PRM channels used for analysis of frataxin. Therefore, we do not anticipate any issues with assay performance so long as standard curves are prepared for every new analytical run.

\section{Sample Processing and Immunoprecipitation of Frataxin}

Frataxin forms high molecular weight $(>600 \mathrm{kDa})$ oligomers in an iron-dependent manner. ${ }^{36-38}$ In order to effectively extract frataxin from platelets before a high-speed centrifugation step that removes cell debris, $1 \%$ SDS at $95{ }^{\circ} \mathrm{C}$ was used to denature cell lysates (Figure 3). Samples with 1\% SDS were later diluted ten times with IP-lysis buffer to accommodate antibody binding. Western blot analysis showed that SDS-denaturation resulted in higher amounts of endogenous frataxin and more of the SILAC-labeled frataxin added to the samples was also more soluble. Because our goal was to quantify frataxin levels lower than $0.2 \mathrm{pg} / \mu \mathrm{g}$, an enrichment step was necessary before LC-MS detection (Figure 3). Numerous antifrataxin monoclonal antibodies (mAbs) were tested before it was found that mAb 1D9 had the strongest binding with the antigen. A substantial number of additional proteins were captured by the $\mathrm{mAb}$ and were eluted with frataxin from the beads (Figure S-5A,B, lane 2). Most of these proteins (even those with molecular weights $<50 \mathrm{kDa}$ ) were removed with a $50 \mathrm{kDa}$ cutoff filter (Figure S-5A,B, lane 3).

Light and heavy chains that arose from the mAb were not removed by filtration, and they caused suppression of ionization in source of the mass spectrometer limiting the assay sensitivity. Covalently linking mAbs to the beads is known to prevents loss of heavy and light $\mathrm{mAb}$ chains. ${ }^{39,40} \mathrm{DMP}$ proved to be an efficient cross-linker so that it was possible to 
enrich platelet frataxin by $>70 \%$ by an overnight incubation with the DMP cross-linked magnetic beads (Figure S-5A,B, lane 4). The heavy and light mAb chains remained bound to the beads, but proteins that eluted from the noncovalently bound $\mathrm{mAb}$ were also detected even after stringent washing (Figure S-5A,B, lane 4). Fortunately, they were readily removed by the $50 \mathrm{kDa}$ filter (Figure $\mathrm{S}-5 \mathrm{~A}, \mathrm{~B}$, lane 5 ).

\section{Method Validation Using IP-UHPLC-PRM/HRMS and SILAC-Labeled Frataxin}

Two rounds of frataxin depletion of platelets using an antifrataxin antibody were performed. Western blot and LC-MS analysis showed that more than $>99.5 \%$ frataxin was depleted, while the cell lysate protein composition remained unchanged. Calibration curves were constructed at ten different concentrations spanning 3 orders of magnitude (0.078-40.0 $\mathrm{pg} / \mu \mathrm{g}$ protein) using frataxin-depleted platelet lysates $(500 \mu \mathrm{g})$ as the matrix. Because frataxin-depleted platelet lysates are difficult to prepare, a standard curve was also prepared by adding the standards to BSA $(500 \mu \mathrm{g})$ as an alternative surrogate matrix. Overlapping linear standard curves were obtained for each of the three peptides with $r^{2}$ values $>0.999$ for both the frataxin-depleted platelet protein and the BSA matrix (Figure S-6A-C).

Furthermore, similar values were found when mean area ratios of analyte to internal standard for the three peptides were plotted against frataxin concentrations (Figure S-6D).

The LLOQ was set at $0.078 \mathrm{pg} / \mu \mathrm{g}$ protein, which is 20 -fold lower than the lowest amount ever reported in FA platelets (Table 1). Accuracy and precision for the LLOQ using frataxindepleted platelet protein matrix were well within the limits of acceptance: intraday $(n=5)$ : precision $5.1 \%$, accuracy $96.8 \%$; interday $(n=5)$ : precision $3.7 \%$, accuracy $101.0 \%$ (Table S-3A). Therefore, this conservative LLOQ readily met the criteria required by the FDA of precision better than $15 \%$ and accuracy of between $85 \%$ and $115 \%$.

Additional validation was performed using quality control (QC) samples at three different concentrations according to FDA guidance ${ }^{41}$ with low (LQC, $0.25 \mathrm{pg} / \mu \mathrm{g}$ protein), middle (MQC, $2 \mathrm{pg} / \mu \mathrm{g}$ protein), and high (HQC, $30 \mathrm{pg} / \mu \mathrm{g}$ protein) $\mathrm{QC}$ samples prepared in frataxin-depleted platelet protein. Precision for intraday $(n=5)$ QC analysis was $2.0-5.1 \%$ and accuracy was $90-103.4 \%$. Precision of interday $(n=5)$ QC analysis was $1.6-4.8 \%$ and accuracy was $97.0-101.1 \%$ (Table S-3A). Method validation was also conducted using BSA as matrix instead of frataxin-depleted platelet protein. Similar precision and accuracies were obtained: intraday $(n=5)$ : precision $1.0-1.5 \%$, accuracy $94.5-107.7 \%$; interday $(n=3)$ : precision 1.3-3.1\%, accuracy $97.5-105.2 \%$ (Table S-3B). Our observation suggests that there is no matrix effect for the range of frataxin concentration we examined. Therefore, calibration curves and QCs prepared using BSA as surrogate matrix can be used for future analysis.

\section{Platelet Frataxin Levels in Unaffected Control Subjects and FA Cases}

To evaluate clinical utility of the IP 2D-nano-UHPLC-PRM/MS method, frataxin levels were quantified in FA platelets $(n=7$; Table S-1) and control platelets $(n=7)$. Typical chromatograms for platelet frataxin from an FA case are shown in Figure 4A,B, respectively. All samples were within the linear range of the standard curves. The frataxin level (mean \pm $\mathrm{SD})$ in platelets from control unaffected subjects was $9.4 \pm 2.6 \mathrm{pg} / \mu \mathrm{g}$ protein. The mean 
level for FA cases was $74.5 \%$ lower than controls at $2.4 \pm 0.6 \mathrm{pg} / \mu \mathrm{g}$ (Figure $5 \mathrm{~A}$ ). There was no overlap between controls and FA cases (Figure 5A), which meant the assay had 100\% specificity and $100 \%$ sensitivity for discriminating control and FA platelets. Despite the small sample size of FA cases $(n=7)$, there was an inverse relationship of frataxin levels with the total number of GAA repeat lengths (Figure 5B), which almost reached statistical significance $\left(y=-0.0018 x+5.13 ; r^{2}=0.616, p=0.067\right)$.

To evaluate the consistency for each peptide in the control and FA platelets, frataxin levels determined from each of the individual tryptic peptides were compared with each other (Figure S-7A-C). Excellent correlations were found for all three peptides from all the platelet samples with $r^{2}$ value ranging from 0.957 to 0.980 . This high consistency confirmed that the SILAC-labeled frataxin standard corrected for the variations in IP and trypsin digestion efficiency. It also confirmed that there were no post-translational modifications on the platelet frataxin tryptic peptides that were analyzed.

\section{CONCLUSION}

MS-based proteomics approaches have identified frataxin as one of the 4497 human platelet proteins. ${ }^{42-44}$ Similar approaches failed to detect frataxin as one of the 2650 human erythrocyte proteins, ${ }^{45}$ although it was detected by the DI assay (Table 1). This led to our development of a more sensitive and specific stable isotope dilution IP 2D-nano-UHPLCPRM/MS method (Figure 3). A SILAC-labeled standard (Figure S-3) facilitated accurate quantification of platelet frataxin because it corrected for losses during IP and trypsin digestion. ${ }^{46,47}$ The assay was highly precise and accurate (Table S-3). Variation of immunoprecipitation efficiency was noticed among different batches of samples, likely caused by the filtration or antibody conjugation efficiency, or matrix effects. Although this variation had very little impact on the LC-MS analysis, it reinforces the importance of using a SILAC internal standard to compensate for these variations as well as the authentic protein for preparing standard curves.

It is noteworthy that platelet frataxin levels in unaffected controls did not overlap with FA cases (Figure 5A). Consequently, the assay had $100 \%$ sensitivity and $100 \%$ specificity for discriminating the controls from FA cases. A previously reported DI method for platelet frataxin had a sensitivity for distinguishing normal and FA platelet frataxin of $76.5 \%$ and a specificity of only $66.7 \%$. This was because the frataxin values for four of the nine controls overlapped with 17 of the FA cases and values from three of the FA cases overlapped with the nine controls. ${ }^{28}$ The DI method also underestimated the amount of control platelet frataxin and FA platelet frataxin (Table 1) by $70 \%$ and 58\%, respectively. Although an inverse relationship between FA platelet frataxin levels and total GAA repeat lengths was observed, it did not reach statistical significance (Figure 5B, $p=0.067$ ). This likely reflects the small number of subjects tested here and the relative inaccuracy of GAA repeat testing. However, the intercept on the $y$-axis (GAA repeat lengths $=0$ ) corresponded to $5.1 \mathrm{pg} / \mu \mathrm{g}$ protein (Figure 5B). Interestingly, $5.1 \mathrm{pg} / \mu \mathrm{g}$ protein is close to the level found for the lowest unaffected normal control $(6.1 \mathrm{pg} / \mu \mathrm{g}$ protein) where total GAA repeat lengths were $<80$. This suggests that it will be possible to distinguish platelet frataxin levels in carriers with GAA repeats on only one $F X N$ allele from both FA cases and unaffected subjects. 
The high sensitivity and specificity of the assay will also make it possible, for the first time, to rigorously evaluate the effect of new therapeutic strategies that are being employed to upregulate frataxin expression in human subjects. ${ }^{21}$ This will avoid controversial filings to the FDA such as those that occurred recently with dystrophin (another platelet protein ${ }^{48}$ ) and the DMD drug eteplirsen. ${ }^{4}$ Furthermore, mouse and monkey models can be employed to determine the relationship between levels in platelets and affected tissues. This will require only minor modifications to the 2D nano-UHPLC-PRM/MS method because of the homology in amino acid sequences of mouse (95.4\% similarity) and monkey frataxin ( $98.5 \%$ similarity) when compared with human frataxin.

\section{Supplementary Material}

Refer to Web version on PubMed Central for supplementary material.

\section{Acknowledgments}

We gratefully acknowledge support of the Hamilton and Finneran families, the Penn Medicine/CHOP Friedreich's Ataxia Center of Excellence, and NIH grants P42ES023720, P30ES013508, R01FD006029, T32ES01985, and UL1TR001878.

\section{References}

1. Hoffman EP, Brown RHJ, Kunkel LM. Cell. 1987; 51(6):919-928. [PubMed: 3319190]

2. Ito H, Fujita K, Tagawa K, Chen X, Homma H, Sasabe T, Shimizu J, Shimizu S, Tamura T, Muramatsu S-I, Okazawa H. EMBO Mol. Med. 2015; 7(1):78-101. [PubMed: 25510912]

3. Campuzano V, Montermini L, Molto MD, Pianese L, Cossee M, Cavalcanti F, Monros E, Rodius F, Duclos F, Monticelli A, Zara F, Canizares J, Koutnikova H, Bidichandani SI, Gellera C, Brice A, Trouillas P, De Michele G, Filla A, De Frutos R, Palau F, Patel PI, Di Donato S, Mandel JL, Cocozza S, Koenig M, Pandolfo M. Science. 1996; 271(5254):1423-1427. [PubMed: 8596916]

4. Lancet. 2016; 388(10052):1350.

5. Kesselheim AS, Avorn J. JAMA. 2016; 316(22):2357-2358. [PubMed: 27775756]

6. Delatycki MB, Williamson R, Forrest SM. J. Med. Genet. 2000; 37(1):1-8. [PubMed: 10633128]

7. Chamberlain S, Shaw J, Rowland A, Wallis J, South S, Nakamura Y, von Gabain A, Farrall M, Williamson R. Nature. 1988; 334(6179):248-250. [PubMed: 2899844]

8. Santos R, Lefevre S, Sliwa D, Seguin A, Camadro J-M, Lesuisse E. Antioxid. Redox Signaling. 2010; 13(5):651-690.

9. Pandolfo M. Semin Neurol. 1999; 19(3):311-321. [PubMed: 12194387]

10. Cossee M, Durr A, Schmitt M, Dahl N, Trouillas P, Allinson P, Kostrzewa M, Nivelon-Chevallier A, Gustavson KH, Kohlschutter A, Muller U, Mandel JL, Brice A, Koenig M, Cavalcanti F, Tammaro A, De Michele G, Filla A, Cocozza S, Labuda M, Montermini L, Poirier J, Pandolfo M. Ann. Neurol. 1999; 45(2):200-206. [PubMed: 9989622]

11. Lill R, Hoffmann B, Molik S, Pierik AJ, Rietzschel N, Stehling O, Uzarska MA, Webert H, Wilbrecht C, Muhlenhoff U. Biochim. Biophys. Acta, Mol. Cell Res. 2012; 1823(9):1491-1508.

12. Braymer JJ, Lill RJ. Biol. Chem. 2017; 292(31):12754-12763.

13. Lill R, Dutkiewicz R, Freibert SA, Heidenreich T, Mascarenhas J, Netz DJ, Paul VD, Pierik AJ, Richter N, Stumpfig M, Srinivasan V, Stehling O, Muhlenhoff U. Eur. J. Cell Biol. 2015; 94(7-9): 280-291. [PubMed: 26099175]

14. Patel M, Isaacs CJ, Seyer L, Brigatti K, Gelbard S, Strawser C, Foerster D, Shinnick J, Schadt K, Yiu EM, Delatycki MB, Perlman S, Wilmot GR, Zesiewicz T, Mathews K, Gomez CM, Yoon G, Subramony SH, Brocht A, Farmer J, Lynch DR. Ann. Clin. Transl. Neurol. 2016; 3(9):684-694. [PubMed: 27648458] 
15. Pousset F, Legrand L, Monin M-L, Ewenczyk C, Charles P, Komajda M, Brice A, Pandolfo M, Isnard R, Tezenas du Montcel S, Durr A. JAMA Neurol. 2015; 72(11):1334-1341. [PubMed: 26414159]

16. Harding AE. Brain. 1981; 104(3):589-620. [PubMed: 7272714]

17. Evans-Galea MV, Pebay A, Dottori M, Corben LA, Ong SH, Lockhart PJ, Delatycki MB. Hum. Gene Ther. 2014; 25(8):684-693. [PubMed: 24749505]

18. Wilson RB. J. Child Neurol. 2012; 27(9):1212-1216. [PubMed: 22791549]

19. Aranca TV, Jones TM, Shaw JD, Staffetti JS, Ashizawa T, Kuo S-H, Fogel BL, Wilmot GR, Perlman SL, Onyike CU, Ying SH, Zesiewicz TA. Neurodegener Dis Manag. 2016; 6(1):49-65. [PubMed: 26782317]

20. Kearney M, Orrell RW, Fahey M, Brassington R, Pandolfo M. Cochrane Database Syst. Rev. 2016; 8:CD007791.

21. Strawser C, Schadt K, Hauser L, McCormick A, Wells M, Larkindale J, Lin H, Lynch DR. Expert Rev. Neurother. 2017; 17:895. [PubMed: 28724340]

22. Basu SS, Deutsch EC, Schmaier AA, Lynch DR, Blair IA. Bioanalysis. 2013; 5(24):3009-3021. [PubMed: 24320127]

23. Worth AJ, Basu SS, Deutsch EC, Hwang W-T, Snyder NW, Lynch DR, Blair IA. Bioanalysis. 2015; 7(15):1843-1855. [PubMed: 26295986]

24. Mendell JR, Rodino-Klapac LR, Sahenk Z, Roush K, Bird L, Lowes LP, Alfano L, Gomez AM, Lewis S, Kota J, Malik V, Shontz K, Walker CM, Flanigan KM, Corridore M, Kean JR, Allen HD, Shilling C, Melia KR, Sazani P, Saoud JB, Kaye EM. Ann. Neurol. 2013; 74(5):637-647. [PubMed: 23907995]

25. Gakh O, Cavadini P, Isaya G. Biochim. Biophys. Acta, Mol. Cell Res. 2002; 1592(1):63-77.

26. Schmucker S, Argentini M, Carelle-Calmels N, Martelli A, Puccio H. Hum. Mol. Genet. 2008; 17(22):3521-3531. [PubMed: 18725397]

27. Condo I, Ventura N, Malisan F, Rufini A, Tomassini B, Testi R. Hum. Mol. Genet. 2007; 16(13): 1534-1540. [PubMed: 17468497]

28. Selak MA, Lyver E, Micklow E, Deutsch EC, Onder O, Selamoglu N, Yager C, Knight S, Carroll M, Daldal F, Dancis A, Lynch DR, Sarry J-E. Mitochondrion. 2011; 11(2):342-350. [PubMed: 21147271]

29. Plasterer HL, Deutsch EC, Belmonte M, Egan E, Lynch DR, Rusche JR. PLoS One. 2013; 8(5):e63958. [PubMed: 23691127]

30. Campuzano V, Montermini L, Lutz Y, Cova L, Hindelang C, Jiralerspong S, Trottier Y, Kish SJ, Faucheux B, Trouillas P, Authier FJ, Durr A, Mandel JL, Vescovi A, Pandolfo M, Koenig M. Hum. Mol. Genet. 1997; 6(11):1771-1780. [PubMed: 9302253]

31. Gill SC, von Hippel PH. Anal. Biochem. 1989; 182(2):319-326. [PubMed: 2610349]

32. Arnold ME, Booth B, King L, Ray C. AAPS J. 2016; 18(6):1366-1372. [PubMed: 27514862]

33. MacLean B, Tomazela DM, Shulman N, Chambers M, Finney GL, Frewen B, Kern R, Tabb DL, Liebler DC, MacCoss M. J. Bioinformatics. 2010; 26(7):966-968.

34. Xia H, Cao Y, Dai X, Marelja Z, Zhou D, Mo R, Al-Mahdawi S, Pook MA, Leimkuhler S, Rouault TA, Li K. PLoS One. 2012; 7(10):e47847. [PubMed: 23082224]

35. Lee-Peng FC, Hermodson MA, Kohlhaw GB. J. Bacteriol. 1979; 139(2):339-345. [PubMed: 378964]

36. Cavadini P, O’Neill HA, Benada O, Isaya G. Hum. Mol. Genet. 2002; 11(3):217-227. [PubMed: 11823441]

37. Karlberg T, Schagerlof U, Gakh O, Park S, Ryde U, Lindahl M, Leath K, Garman E, Isaya G, AlKaradaghi S. Structure. 2006; 14(10):1535-1546. [PubMed: 17027502]

38. Li H, Gakh O, Smith DY 4, Isaya GJ. Biol. Chem. 2009; 284(33):21971-21980.

39. Whiteaker JR, Zhao L, Zhang HY, Feng L-C, Piening BD, Anderson L, Paulovich AG. Anal. Biochem. 2007; 362(1):44-54. [PubMed: 17241609]

40. Fredolini C, Bystrom S, Pin E, Edfors F, Tamburro D, Iglesias MJ, Haggmark A, Hong M-G, Uhlen M, Nilsson P, Schwenk JM. Expert Rev. Proteomics. 2016; 13(1):83-98. [PubMed: 26558424] 
41. Bansal S, DeStefano A. AAPS J. 2007; 9(1):E109-E114. [PubMed: 17408234]

42. Burkhart JM, Vaudel M, Gambaryan S, Radau S, Walter U, Martens L, Geiger J, Sickmann A, Zahedi RP. Blood. 2012; 120(15):e73-e82. [PubMed: 22869793]

43. Lee H, Chae S, Park J, Bae J, Go E-B, Kim S-J, Kim H, Hwang D, Lee S-W, Lee S-Y. Mol. Cell. Proteomics. 2016; 15(11):3461-3472. [PubMed: 27601597]

44. Stokhuijzen E, Koornneef JM, Nota B, van den Eshof BL, van Alphen FPJ, van den Biggelaar M, van der Zwaan C, Kuijk C, Mertens K, Fijnvandraat K, Meijer AB. J. Proteome Res. 2017; 16(10): 3567-3575. [PubMed: 28823163]

45. Bryk AH, Wisniewski JR. J. Proteome Res. 2017; 16(8):2752-2761. [PubMed: 28689405]

46. Lowenthal MS, Liang Y, Phinney KW, Stein SE. Anal. Chem. 2014; 86(1):551-558. [PubMed: 24294946]

47. Wang Q, Zhang S, Guo L, Busch CM, Jian W, Weng N, Snyder NW, Rangiah K, Mesaros C, Blair IA. Bioanalysis. 2015; 7(22):2895-2911. [PubMed: 26394123]

48. Stokhuijzen E, Koornneef JM, Nota B, van den Eshof BL, van Alphen FPJ, van den Biggelaar M, van der Zwaan C, Kuijk C, Mertens K, Fijnvandraat K, Meijer AB. J. Proteome Res. 2017; 16(10): 3567-3575. [PubMed: 28823163] 


\begin{tabular}{|c|c|c|c|c|}
\hline & & & & MPP \\
\hline 10 & 20 & 30 & 40 & 50 \\
\hline MWTLGRRAVA & GLLASPSPAQ & AQTLTRVPRP & AELAPLCGRR & GLRTDIDATC \\
\hline 60 & 70 & $\frac{M}{80}$ & 90 & 100 \\
\hline TPRRASSNQR & GLNQIWNVKK & QSVYLMNLRK & SGTLGHPGSL & DETTYERLAE \\
\hline 110 & 120 & 130 & 140 & 150 \\
\hline ETLDSLAEFF & EDLADKPYTF & EDYDVSFGSG & VLTVKLGGDL & GTYVINKQTP \\
\hline 160 & 170 & 180 & 190 & 200 \\
\hline NKQI WLSSPS & SGPKRYDWTG & KWWVYSHDGV & SLHELLAAEL & TKALKTKLDL \\
\hline 210 & & & & \\
\hline SSLAYSGKDA & & & & \\
\hline
\end{tabular}

Figure 1.

Sequence of full-length $23135 \mathrm{Da}$ frataxin (1-210) showing the mitochondrial processing peptidase (MPP) cleavage sites to give mature frataxin (81-210, green). 

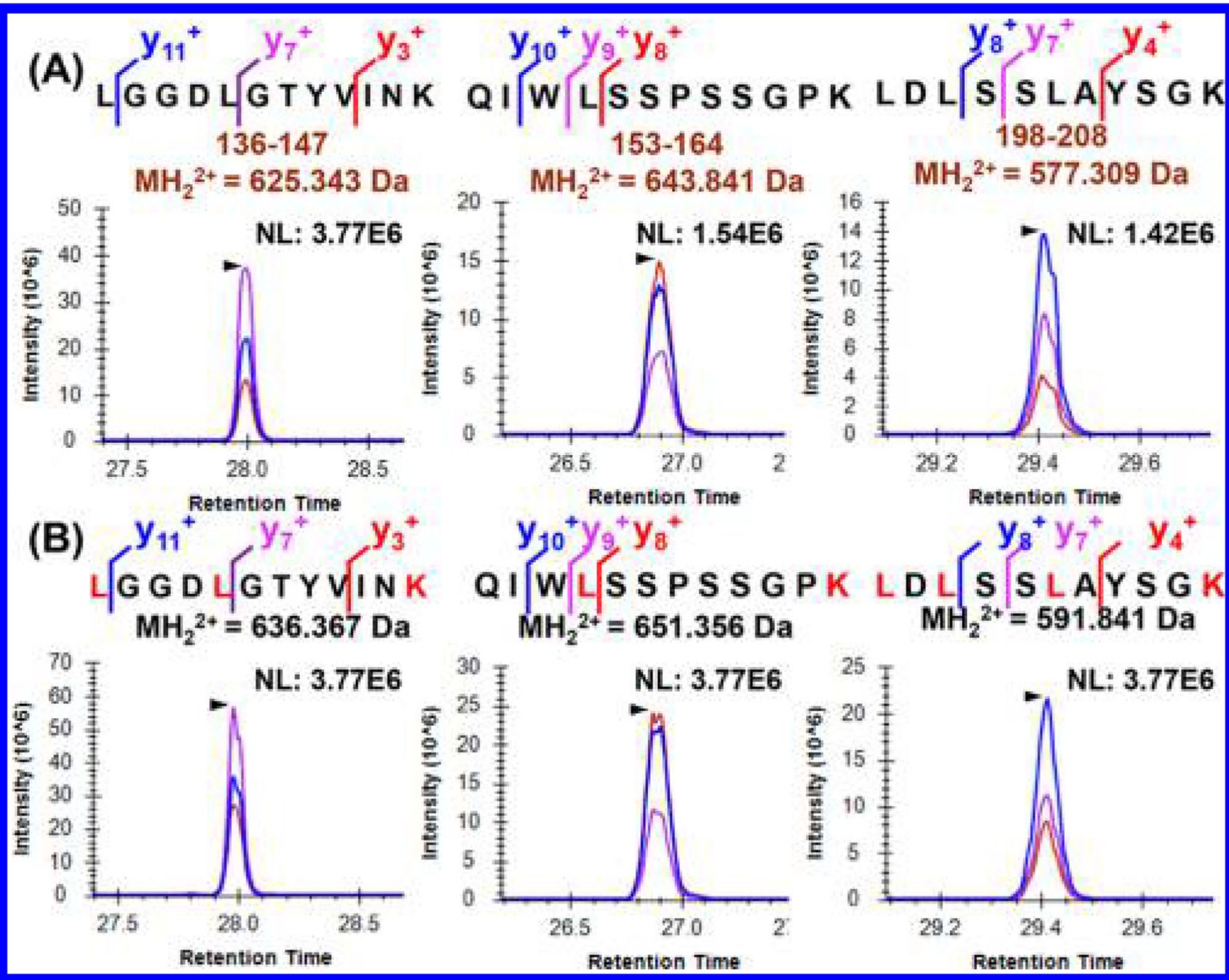

Figure 2.

Typical 2D-nano-UHPLC-PRM/MS chromatograms of three PRM transitions for three peptides. (A) Endogenous peptides; (B) Stable isotope labeled peptides (K (red) $=\left[{ }^{13} \mathrm{C}_{6}\right.$ $\left.{ }^{15} \mathrm{~N}_{2}\right]$-lysine, $\mathrm{L}$ (red) $=\left[{ }^{13} \mathrm{C}_{6}{ }^{15} \mathrm{~N}_{1}\right]$-leucine). The chromatograms are from one sample used for standard curve construction. Light frataxin was $10 \mathrm{pg} / \mu \mathrm{g}$, and heavy frataxin was 40 $\mathrm{pg} / \mu \mathrm{g}$. 


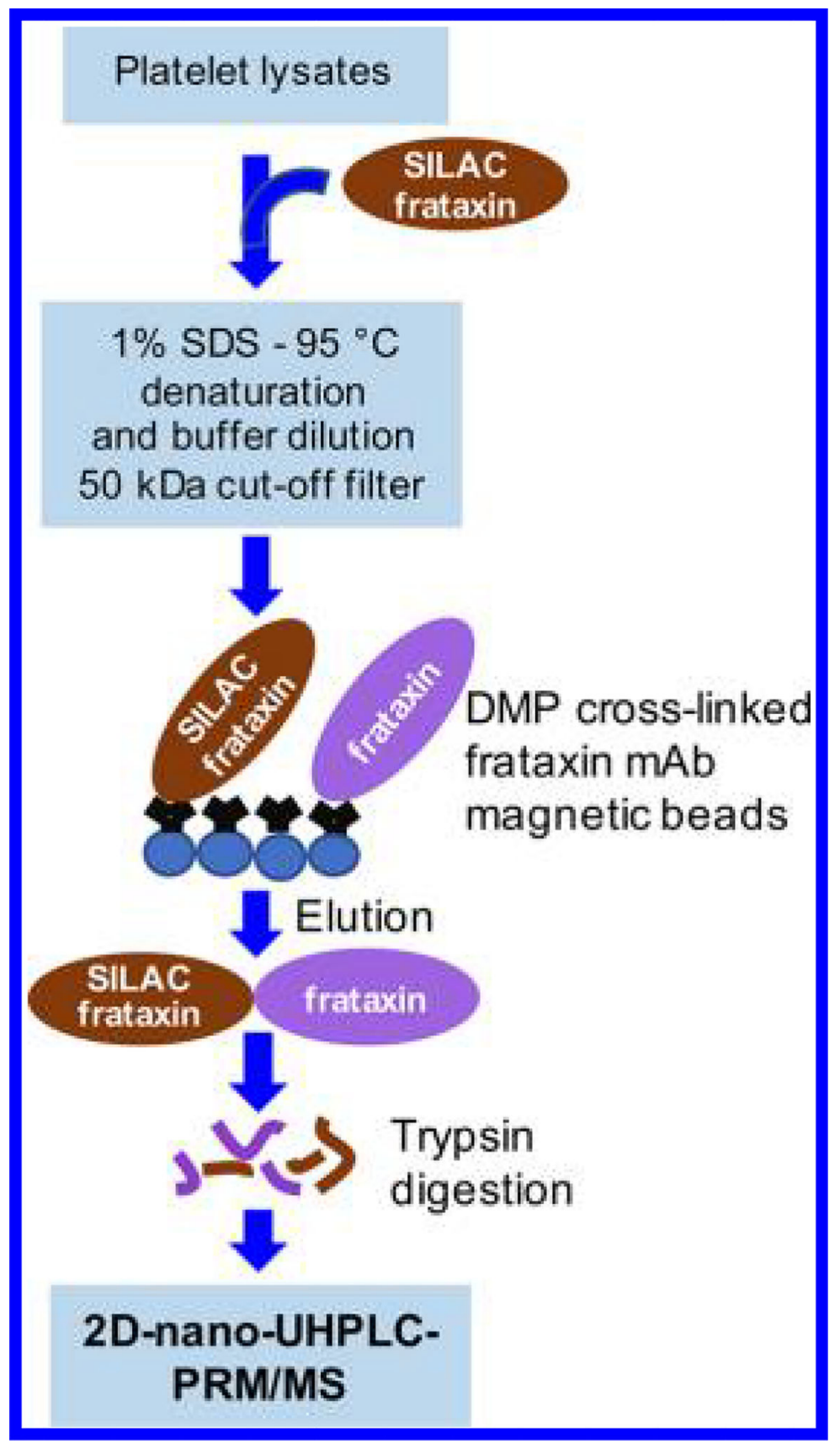

Figure 3.

Platelet frataxin sample processing procedure. 


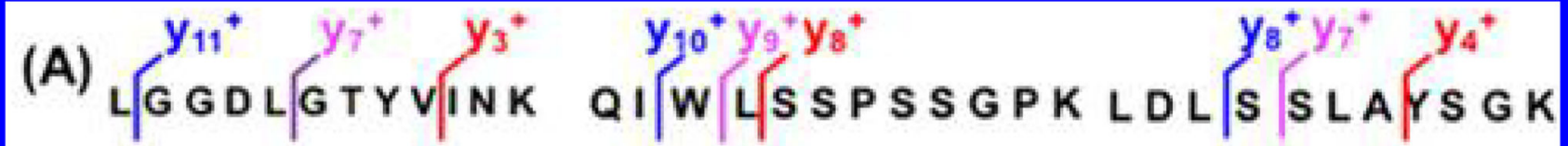

$136-147$

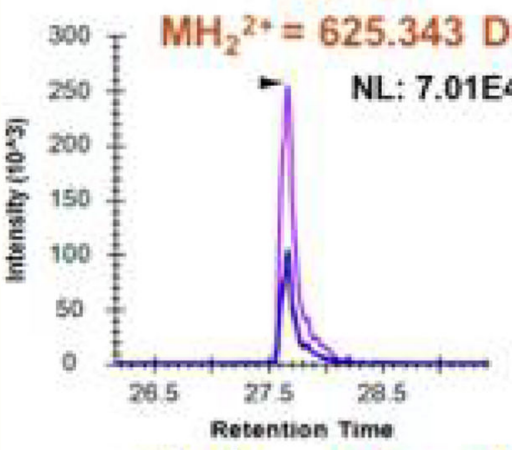

(B)
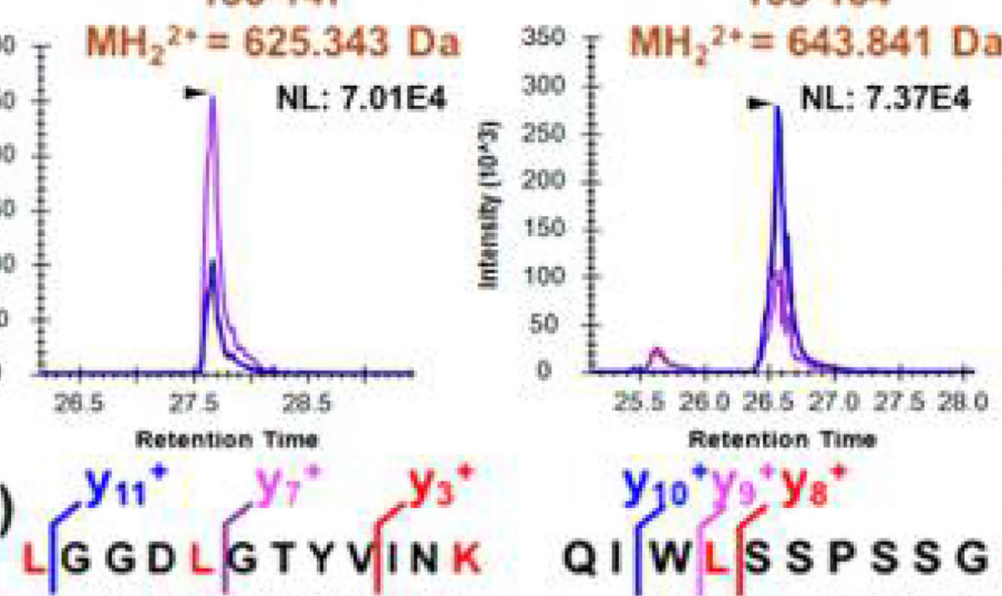

153-164

198-208

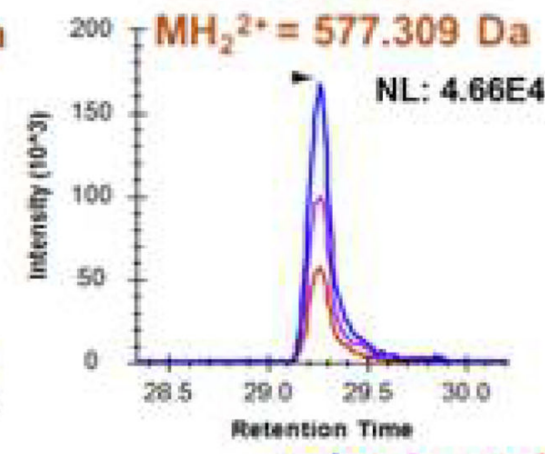

PK LDL/S SLAYSGK

$\mathbf{y}_{10}{ }^{*} y_{9}{ }^{*} \mathrm{y}_{8}{ }^{*}$
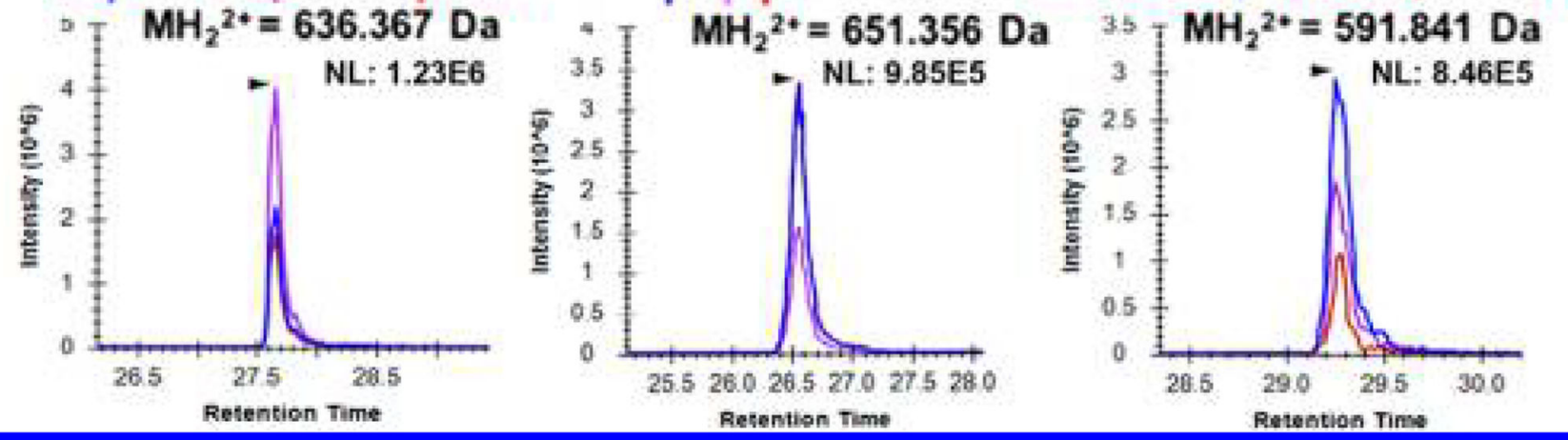

Figure 4.

2D-nano-UHPLC-PRM/MS chromatograms from an FA platelet sample with $2.1 \mathrm{pg} / \mathrm{g}$ protein. (A) Three PRM/MS transitions for endogenous platelet frataxin tryptic peptides: $\mathrm{L}^{136}$ GGDLGTYVINK ${ }^{147}, \mathrm{Q}^{153}$ IWLSSPSSGPK $^{164}$, and L ${ }^{198}$ DLSSLAYSGK $^{208}$. (B) Three $\mathrm{PRM} / \mathrm{MS}$ transitions from the corresponding SILAC-labeled analogs (K (red) $=\left[{ }^{13} \mathrm{C}_{6}{ }^{15} \mathrm{~N}_{2}\right]-$ lysine, $\mathrm{L}$ (red) $=\left[{ }^{13} \mathrm{C}_{6}{ }^{15} \mathrm{~N}_{1}\right]$-leucine) . 


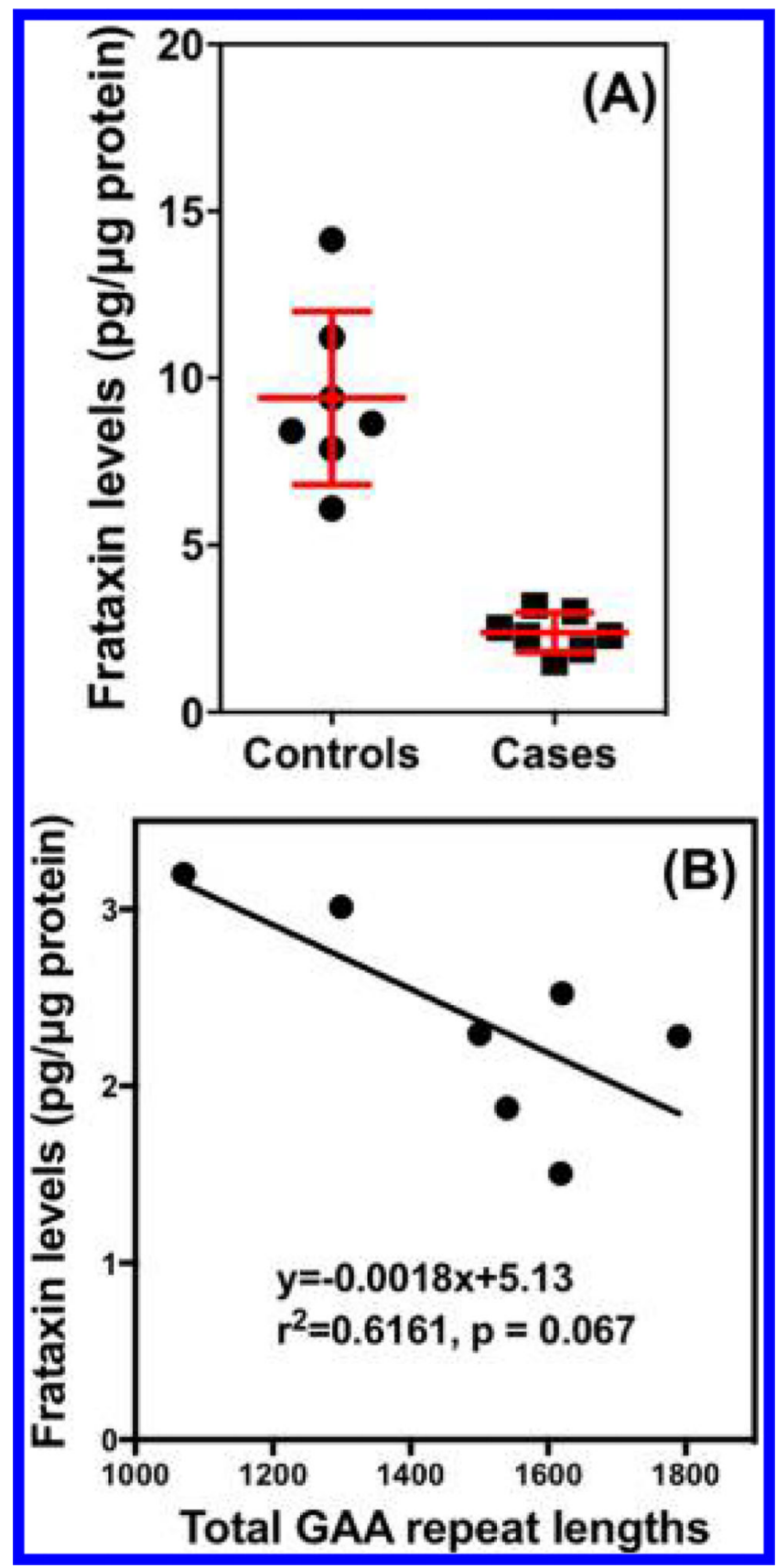

Figure 5.

Platelet frataxin levels. (A) Controls (mean $\pm \mathrm{SD}$ ), $9.4 \pm 2.6 \mathrm{pg} / \mu \mathrm{g}$ protein. FA cases, 2.4 $\pm 0.6 \mathrm{pg} / \mu \mathrm{g}$ protein. (B) Correlation of individual frataxin levels with sum of GAA repeat lengths from both FXN alleles. 


\section{로을}

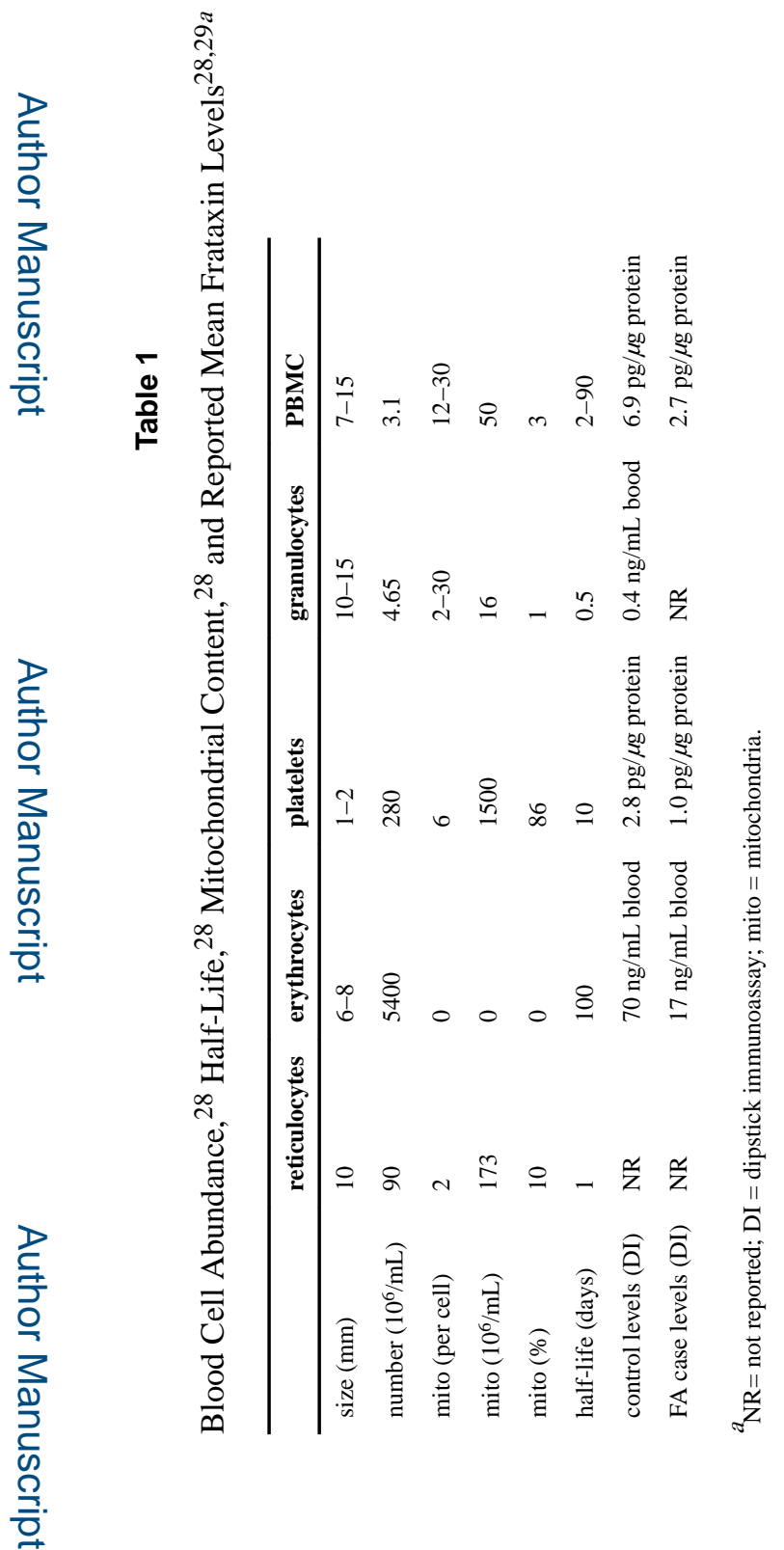

Anal Chem. Author manuscript; available in PMC 2019 February 06. 